Artigo Original

\title{
Mulher e Vôlei de Praia: memórias de Tia Leah
}

\author{
Lenice Peluso de Oliveira $^{1}$ \\ Ludmila Mourão ${ }^{2}$ \\ Vera Lúcia de Menezes Costa ${ }^{12}$ \\ ${ }^{1}$ PROCIMH da Universidade Castelo Branco, Rio de Janeiro, RJ, Brasil \\ ${ }^{2}$ PPGEF da Universidade Gama Filho, Rio de Janeiro, RJ, Brasil
}

\begin{abstract}
Resumo: O estudo buscou, na memória de pioneiros e nas lembranças dos que viveram o Vôlei de Praialazer nas décadas de 1930 e1940, delinear o perfil de Tia Leah na gestão, divulgação e visibilidade do Vôlei de Praia no Rio de Janeiro, através de entrevistas e recortes encontrados na literatura. O resgate dos depoimentos de oito pioneiros da modalidade à época tem na abordagem da História Oral seu aporte teórico e metodológico. A partir da reorganização do passado, houve a possibilidade de mostrar uma identidade sociocultural do Vôlei de Praia no seu início. A sociabilidade entre os jogadores foi fundamental para o convívio de diversas gerações. A gestão de Tia Leah na rede do Posto Seis em Copacabana, foi um marco do Vôlei de Praia, promovendo a equidade esportiva entre os homens e as mulheres que participaram nos jogos da rede.
\end{abstract}

Palavras-chave: Mulher. Vôlei de Praia. Memórias.

\section{Woman and beach volleyball: memories of Tia Leah}

\begin{abstract}
From the memory of the pioneers and from the remembrance of those who had experienced the Beach Volley for leisure, the study tried to outline Aunt Leah's profile in the management, disclosure and visibility of the Beach Volley in Rio de Janeiro, through interviews and newspaper cuts found in the literature. The retrieval of the testimonies of eight pioneers of that modality at that time has in the approach to the Oral History its theoretical and methodological contribution. From the reorganization of the past, it was possible to show a socio-cultural identity of the Beach Volley from its very beginning. The sociability among the players was critical to the relationship of several generations. Aunt Leah's management of the net at Posto Seis in Copacabana was a milestone of the Beach Volley as it promoted equal roles among men and women who participated in the games in that net.
\end{abstract}

Key Words: Women. Beach volley. Memories.

\section{Introdução}

A cidade do Rio de Janeiro, principal centro urbano do Brasil do século XIX até meados de século XX, foi a capital da Colônia em 1763, capital do Império em 1815 e capital da República de 1889 até 1961, destacando-se por sua importância política e como pólo difusor de cultura e de tendências vanguardistas nas diversas esferas da vida social. Apesar da perda do status que desfrutou enquanto capital do país, manteve-se entre os principais centros financeiros e comerciais e é o maior ponto de atração de turistas - nacionais e estrangeiros devido à beleza de suas paisagens, de suas praias, e ao estilo carioca de vida.

A praia, o território do vazio de Corbin (1989), era um lugar em que se mesclavam comportamentos e atitudes de todas as classes sociais, obedecendo ao imperativo de dinamicidade da cultura.

$\mathrm{Na}$ cidade do Rio de Janeiro, a praia se consagrou como um espaço de convívio, mas também de tolerância aos preconceitos (COSTA;

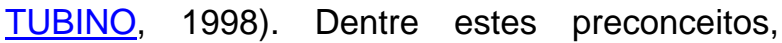
aquele que, atrelado à organização social patriarcalista, reservava às mulheres os cuidados com a casa, marido e filhos. A essa imagem ideal de ser feminina juntava-se a imposição da invisibilidade e discrição: as mulheres iam ao mar, cheias de roupas e separadas dos homens. Apenas no inicio do século $X X$ começaram a banhar-se, as mais ousadas vestindo maiôs.

A par de outras conquistas feministas, as mulheres foram lentamente garantindo sua participação no esporte (GOELLNER, 2003; MOURÃO, 1998). De início, estavam destinadas à prática de atividades físico-esportivas que não colocassem em risco a sua frágil estrutura corporal, como a ginástica, a dança, a natação, o tênis entre outras modalidades em que a graça e a beleza sobressaíssem ${ }^{1}$. Mas em 1927, a

\footnotetext{
${ }^{1}$ Pierre de Coubertin, idealizador dos Jogos Olímpicos, entendia que o esporte era incompatível com a graça e a elegância femininas. Só nos Jogos de Estocolmo, em 1912, as mulheres foram convidadas a participar oficialmente dos Jogos Olímpicos em provas adequadas à "natureza feminina";
} 
professora Yara Vaz, aos 17, anos praticava esportes na praia do Leblon; "esta pioneira, mostrava seu corpo trabalhado em exercícios diários, corria e nadava da praia do Leblon à do Arpoador, em Ipanema" (MOURÃO, 1998).

O progresso feminino no esporte foi mais efetivo a partir da década de 1930. No entanto, devido à forte influência da moral patriarcal, as mulheres deveriam praticar atividades físicas em grupos exclusivamente femininos, nas escolas ou nos clubes. As praias tornaram-se o espaço em que tais preceitos puderam ser questionados, e até modificados. Corpos seminus, pés descalços e encontro entre os sexos facilitaram, no campo do lazer, o partilhamento de outras construções culturais, possibilitando que o lazer esportivo na orla recriasse novas práticas, dentre as quais o Vôlei de Praia misto, prática incomum até os anos 1950. O registro do primeiro campeonato em 1947 (JORNAL DOS SPORTS, 3 jan.1947), atesta a apropriação do espaço público esportivo da praia por mulheres que levaram seus conhecimentos adquiridos na escola para lá.

O Vôlei de Praia jogado nas areias de Copacabana, não é o mesmo institucionalizado que encontramos na contemporaneidade. Nos anos 1940, este já contrariava os padrões culturais e esportivos da época: nas redes armadas ao longo da orla, homens e mulheres jogavam juntos, e entre uma partida e outra se banhavam nas águas do mar. Embora a maioria dos jogadores fosse do sexo masculino, o diferencial das equipes mistas experimentava uma mudança de comportamento no esporte. Nas quadras, equipes masculinas e femininas disputavam entre si, na praia se misturavam em práticas como lazer. O contrato lúdico, interposto entre os praticantes, permitia alterações, e uma das mais significativas foi a aproximação de homens e mulheres num mesmo set, equalizando oportunidades de gênero. Mesmo que as diferenças físicas entre homens e mulheres ainda sejam critérios de exclusão da presença feminina no esporte, é possível verificar que as diferenças de gênero no esporte estão menos acirradas, e com isso as mulheres vêm ocupando posições significativas neste campo, desmistificando as características de fragilidade.

Muito apreciada e procurada pelos turistas e pela população da cidade, a praia de Copacabana é um espaço valorizado pelas práticas de atividades físicas e esportes, como vôlei, futevôlei, futebol, frescobol, peteca, entre outras. A praia possui aproximadamente quatro

e paralelamente, o Comitê Organizador reconheceu a mulher como atleta. quilômetros de extensão, iniciando no bairro do Leme (Posto Zero) e terminando no Posto Seis. A área do Posto Seis abrange as seguintes ruas que fazem esquina com a Avenida Atlântica: Francisco Otaviano, Joaquim Nabuco, Rainha Elizabeth, Júlio de Castilhos, Souza Lima e Francisco Sá. Neste local ficou conhecida a rede de Vôlei de Praia da Tia Leah, que se reuniram desde os anos 1930-1940, grupos que praticavam Voleibol, ultrapassando os fins esportivos.

A história que se quer contar com este artigo é produzida a partir da tessitura de uma trama entre a memória e as lembranças dos pioneiros do Vôlei de Praia-lazer no Rio de Janeiro, - desde os anos 1940 até 1980 -, sobre o protagonismo de Tia Leah, na gestão, divulgação e visibilidade do Vôlei de Praia.

O resgate dos depoimentos de oito pioneiros dessa modalidade esportiva tem na abordagem da História Oral seu aporte teórico e metodológico. A História Oral é suportada pelas lembranças, pondo em evidência a memória coletiva, passível de ser usada como fonte histórica. Segundo Nora (1993), memória define o vivido, e história, o elaborado. Resgatar a vivência daqueles atores e trazê-las à tona nos parece relevante para a reconstrução de uma história do Vôlei de Praia no Rio de Janeiro dos anos 1940.

Alberti (2004) reconhece que na entrevista de História Oral há uma vivacidade, um tom especial. Trata-se da experiência de um sujeito, e sua narrativa colore o passado com um valor significativo. Ouvindo-o falar, temos a sensação de que as descontinuidades da história são abolidas e recheadas com emoções, reações, observações e relatos pitorescos. Para a autora, a história opera por descontinuidades, e para conhecer e explicar o que se passou, selecionamos acontecimentos, conjunturas e modos de viver, tornando-os fonte histórica, pistas para se conhecer as diferentes versões do passado relacionadas ao Vôlei de Praia.

Sabendo da fragilidade do resgate da memória, neste caso a partir da História Oral, tivemos o cuidado de associar os depoimentos dos participantes aos registros encontrados no material que nos foi possível coletar em sítios na internet, relatos de antigos jogadores e recortes de jornais, que complementaram as informações, possibilitando uma triangulação entre os dados das diferentes fontes, visando compreender 0 fenômeno e a cultura segundo uma multiplicidade de registros e perspectivas (PEÑ); ECHEVERRY, 2000). 
Conforme diz Halbwachs (1990), "lembrar não é reviver, mas refazer, reconstruir, repensar com imagens e idéias de hoje". O critério de inclusão para seleção dos depoentes foi o fato de todos participarem do vôlei de praia lazer como jogadores durante as décadas de 1950 e 1960, acrescentou-se os depoimentos de "Seu" Nonô, pescador, e atualmente fabricante de rede de voleibol de praia. Quanto aos procedimentos para a realização das entrevistas utilizou-se de gravação na residência de cada sujeito. As fontes que dialogaram com as narrativas fora: Jornal dos Sports, publicações eletrônicas, livros e artigos. Todos os sujeitos assinaram o Termo de Consentimento Livre e Esclarecido e declararam que seus depoimentos poderiam ser utilizados para esta pesquisa, que obteve o número 0067/2009 do parecer de aprovação do Comitê de Ética em Pesquisa Envolvendo Seres Humanos.

\section{Leah: uma mulher promovendo o Vôlei de Praia}

Leah Mendes de Moraes, nascida em 1919, teve contato pela primeira vez com o Voleibol aos 12 anos, no Instituto de Educação, escola de formação de professores localizada no bairro da Tijuca, onde residia. À época, década de 1930, ganhou o prêmio de atleta-destaque da escola ("Tia Leah: a musa do vôlei", 1997). Esse gosto pelo Voleibol ultrapassou os muros da escola, despertando a paixão e a continuidade na prática do esporte, dando início a uma carreira no Voleibol na praia. Hoje, aos 90 anos, Leah (2009), quando provocada a lembrar sua trajetória, conta:

Toda vida eu vivi na praia, comecei a jogar garotinha, aos 15 anos. Naquele tempo só tinha homem, as mulheres não jogavam. Depois que as mulheres foram entrando, gostaram e acabaram ficando. Eu vivo na praia desde garota, no Posto Seis, nunca saí daqui. Quando comecei, era na Rua Joaquim Nabuco, mas depois a minha rede era quase em frente à Rua Souza Lima. Minha rede sempre foi ali, era minha mesmo.

Leah, considerada uma das pioneiras do Vôlei de Praia, fixou sua rede no Posto Seis, em Copacabana. Por lá passaram muitos jogadores de destaque do Voleibol, os anônimos e até mesmo aqueles que se tornaram famosos ${ }^{2}$ nas décadas de 1970-1980. Seu nome é sempre lembrado com carinho pelos apaixonados por Voleibol.

Quando você passa pelo Posto Seis em

\footnotetext{
2 Famosos nas quadras de Voleibol como Bernard, Renan, Montanaro, Bernardinho, Willian, Xandó, Badalhoca, e nas praias como Edinho. Jaqueline por sua vez, brilhou nos dois espaços.
}

Copacabana é impossível não parar um pouquinho para olhar o jogo. Todo dia bem cedinho, ela chega, monta sua rede e vai recebendo os amigos. Tia Leah é assim. Fez das areias da praia um pedaço de sua casa. Desde 1938, quando se mudou para Copacabana com a família, essa menina não parou de jogar. Hoje é respeitada por todas as "feras" do Voleibol. (OS REIS DA PRAIA, 1990, p.30)

Tia Leah, como ficou sendo carinhosamente chamada por todos, não teve filhos. Passava grande parte do seu dia na praia, montava a rede pela manhã e só a desmontava à tarde, "era rato de praia", como ela mesma se denomina. De acordo com Peixoto (1987), "rato de praia" é a definição daquele que passa o dia todo na praia, vai todos os dias, podendo ser visto como o verdadeiro "carioca que se preza". Estes "ratos" transformam a praia em área de lazer, e lá criam grupos que têm o esporte como meio de sociabilidade. No tempo em que a essência da individualidade feminina era reduzida ao espaço privado e a maternidade, Leah ignora essas regras a maior parte tempo, e se dedica ao espaço público da praia carioca dedicando aos esportes, à sociabilidade da rede, e ao jogo de cartas.

$\mathrm{Na}$ rede da Tia Leah, a partir de 1938, um pequeno grupo de mulheres passou a frequentar as quadras da praia de Copacabana. Como diz Tia Leah, podia-se "contar nos dedos" às mulheres que jogavam; por isso todas se conheciam, pois eram as mesmas que participavam dos torneios da Escola Normal, e dos clubes privados, onde eram associadas (PEIXOTO, 2000).

Tia Leah dividia a direção da rede com dois outros sócios, com quem criou todo um sistema de regras. Com a morte de um deles e a transferência de cidade do outro, ela se tornou a única responsável. "Sua rede passou a ser uma das mais conhecidas de Copacabana, despertando a atenção, ainda hoje, de jogadores profissionais de todo o mundo que vêm jogar e treinar." (PEIXOTO, 2000 p.116).

Lucia, sua sobrinha, conta que ela tinha o hábito de fixar sua barraca de sol, sua cadeira, seu garrafão de água e demais acessórios na lateral da quadra. Desta forma tinha total visão sobre que acontecia dentro e fora da quadra.

A praia era uma vitrine, um lugar de
"badalação". Acompanhei a passagem de vários
jogadores de Voleibol nos anos 1970-1980, que
frequentaram a rede da Tia Leah. Inicialmente
para se divertir e se inserir num contexto de
sociabilidade da rede, e depois, com uma visão
no futuro, almejando um melhor
condicionamento físico praticando a modalidade 
de origem, o Voleibol, na areia, e exposição na mídia. No decorrer dos anos, muitos registraram seus nomes na história do Voleibol ou do Vôlei de Praia, como: Bernard, Renan, Montanaro, Bernardinho, Badalhoca, Edinho e Jaqueline. (MORAES, 2009)

A forma carinhosa de ser chamada de "Tia" por todos em sua rede, foi herdada dos sobrinhos Lucia e Vitório, que também jogavam na rede, um apelido que com o passar do tempo ficou conhecido internacionalmente, pois ela recebia em sua rede jogadores estrangeiros. Sinjin Smith e Stoklos a chamavam de "my Brazilian mother" ou "my Rio mother" em cartão autografado em 1989.

Todos seguiam as regras de prática do jogo prescritas por Tia Leah. Os limites da rede eram definidos por ela:

Essa quadra de esporte é totalmente controlada por Tia Leah, que dita as regras do jogo aos participantes de todas as idades. Idosos, jovens, e mesmo profissionais, seguem à risca as condições por ela impostas. Nesse território de sociabilidade só entram os convidados da anfitriã, que, pertencente à família tradicional do bairro, é rigorosa na seleção dos jogadores: os candidatos de origem popular são eliminados. (PEIXOTO, 1995)

Dotada de forte personalidade, culta e elegante, Leah não deixava escolha, era amada ou detestada, não se subordinava à autoridade dos homens da rede e nem de casa.

O espetáculo esportivo atrai e aproxima os jogadores de Vôlei, bem como os espectadores que observam o jogo ao longo da orla, nos bancos dispostos na calçada. Mas para participar dos jogos, é preciso se acostumar às "ordens e broncas" de Tia Leah, segundo suas próprias narrativas.

Além da prática do Vôlei de Praia, conta Moraes (2009), Tia Leah também gostava de jogar baralho e peteca. Mas o Vôlei é a maior paixão de Tia Leah.

No final do Posto Seis, numa colônia de pescadores, Claudionor José da Silva, - "Seu" Nonô, 87 anos -, presenciou a popularização do Vôlei de Praia na cidade do Rio de Janeiro. Pescador desde 1937, ele descreve que "deu conta pela primeira vez do Vôlei de Praia", em frente à Rua Joaquim Nabuco, em 1952, e lembra ainda que a primeira mulher que viu jogar foi Tia Leah:

Ela brigava muito com os jogadores, no intuito de manter a ordem na quadra. Chamava a atenção quando alguém dava um "bandejão", gesto utilizado para pegar as bolas que hoje são recebidas de manchete. Gostava que o jogo seguisse as regras. (NONÔ, 2009)
A praia, que representava um novo espaço de lazer para a sociedade carioca, se tornou ponto de encontro em torno do lúdico.

De acordo com Tubino $(2006$, p. 23, 24),

O esporte-lazer se apoia no princípio do prazer lúdico, no próprio lazer e na utilização construtiva do tempo livre e de liberdade. Esta manifestação esportiva não tem compromisso com as regras institucionais [...] o esporte-lazer, pelo envolvimento das pessoas, nas atividades prazerosas que oferece, ainda proporciona o desenvolvimento de um espírito comunitário, de integração social, fortalecendo parcerias e relações pessoais.

Entre um mergulho e outro, Tia Leah participava de discussões sobre o Voleibol num clima de muita camaradagem. Na sua rede havia uma mescla de gerações, aqueles que jogaram no passado permaneciam no grupo, sentados nos bancos ao redor da rede, sob as barracas. Viravam espectadores assíduos que contavam histórias aos jovens que começavam a integrar o grupo (PEIXOTO, 1995).

Tia Leah comenta que "os jogadores, vez ou outra, faziam apostas; eu nunca vi, apostavam escondidos, eles não deixavam eu ver, eu nunca peguei, eles não davam na pinta" (LEAH, 2009).

As apostas mais comuns naquela época envolviam uma coca-cola ou um jantar para quem ganhasse o jogo.

\section{A liderança de Tia Leah em sua rede}

A postura e a liderança de Leah na rede eram marcas registradas de pioneirismo feminino no esporte, em um período em que a maioria das mulheres ainda não se ocupava deste tipo de atividade. A presença feminina no esporte sul americano foi marcada com a participação, em 1932, de Maria Lenk, nadadora brasileira, nos Jogos Olímpicos de Los Angeles. A mulher começava a apropriar-se de um espaço até então reservado ao masculino.

No espaço da praia de Copacabana, nesta época, Tia Leah, já tinha enorme respeito de todos os jogadores cariocas e estrangeiros. "[...] na rede da Tia Leah ninguém fala palavrões" ( $\underline{\text { OS }}$ REIS DA PRAIA, 1990, p. 30). Este misto de respeito e autoridade é confirmado por Nonô (2009), quando relata que "ela não deixava ninguém falar palavrão. Eu gostava muito dela, ela dava muita 'bronca' e impunha respeito na rede".

De um modo divertido, Moraes (2009) comenta que na rede era uma "democracia absoluta!". "Só eu que mando", era o slogan de Tia Leah. Alguns chegavam a chamá-la de 
"generala" pela forma assertiva com que governava a rede. Com ela não tinha meias palavras. Segundo Peixoto (2000), ela exercia liderança e comando sobre todos aqueles interessados em fazer parte da rede:

Eu que organizava os times, respeitava a ordem de chegada também. Priorizava aquele que chegava à praia, na rede, mais cedo. $O$ primeiro a chegar, era um pescador. Eu joguei até os 70 anos e sempre joguei como levantadora. (LEAH, 2009)

Ao ser indagada sobre de quem era a responsabilidade de dividir ou escolher as equipes em sua rede, Leah (2009) diz: "Era minha, tinha uns maus elementos que queriam jogar e eu não deixava". Na sua rede só jogavam os indicados por outros que já faziam parte do grupo e a escolha dos jogadores passava pelo aval da poderosa senhora. Quando um jogador não cumpria com as expectativas, ela imediatamente o convidava a retirar-se do jogo, alegando, em tom de "gozação", uma desculpa para afastá-lo da quadra. "E eu deixei de escolher um abacaxi para cair numa banana; não é deste jeito que vou ganhar", dizia Tia Leah quando alguém dava prejuízo à sua equipe fazendo erros constantes.

Confirmando sua liderança na rede, Tia Leah afirmava: "A rede é minha, eu seleciono quem eu quero. Agora é a vez dos profissionais, e não tem reclamação, vocês sabem o que pode acontecer!" (apud Peixoto, 2000, p.120). Parecia usar um tom ameaçador quando precisava ceder a rede para os jogadores profissionais de Voleibol de quadra nos anos 1970-1980.

Tudo seguia de acordo com as determinações dela, o que parece ao primeiro olhar, indicar que essa autoridade evidenciada pelos autores se constituía na percepção de Leah, em preservação de território, uma preservação da segurança e do conforto de seus convidados. A cada dia, bem cedo, ela montava a rede e recebia os amigos, mais ou menos por volta das onze e meia horas da manhã, conta Moraes (2009); ia retirando os jogadores e garantindo o espaço àqueles de alto nível, considerados profissionais. Era quando jogadores de Seleção Brasileira e os profissionais dos clubes chegavam e tomavam seus lugares.

Nas malhas da rede da Tia Leah, conforme define Peixoto (1995), a "rainha da rede" ditava as regras. Colocava os jogadores "contra a parede" exigindo obediência e resistência, organizava os times sempre a seu favor. Seu critério era ela jogar ao lado de jovens fortes, e queria a vitória no jogo. Seus companheiros de mais idade não tinham chance no seu time, mesmo que ainda jogassem com vigor. Sua preferência era por jogadores competentes, tanto técnica quanto fisicamente. Tia Leah jogou até 1989, quando contava 70 anos.

A opinião de Ballariny (2009) sobre o comportamento da senhora da rede de Copacabana confirma: "Ela tinha características de centralizadora, tinha o comando da rede mesmo quando não jogava mais. Logo se tornou popular, e através de sua amizade e carisma atraiu grandes nomes deste esporte para sua rede". A liderança era uma de suas características, conquistada ao longo de sua efetiva atuação no vôlei de praia e de sua articulação política em torno da rede, Leah estimulou e visibilizou a inclusão de mulheres nas práticas esportivas das quadras para a praia.

\section{Relatos dos pioneiros}

O esporte, na segunda metade do século $X X$, situou-se "como um dos mais relevantes fenômenos sociais do mundo, pela abrangência do seu envolvimento e de suas relações" (TUBINO, 2001). O Vôlei de Praia se instaurou e cresceu nesse período, agregando em torno de si vários praticantes e admiradores. Tia Leah, como uma das precursoras, contribuiu, com seu jeito de ser, para a divulgação e visibilidade desse esporte.

O depoimento oral dos pioneiros e daqueles que vivenciaram o caminho percorrido pelo Vôlei de Praia desde o seu surgimento confiam a Tia Leah a multiplicação de adeptos e o crescimento deste esporte entre os praticantes na praia.

"Seu" Nonô, o pescador que se transformou em fabricante oficial de rede de Vôlei de Praia no Rio de Janeiro, acompanhou a trajetória de Tia Leah, conviveu com ela lado a lado no Posto Seis e registra em depoimento especial: "Olha, não tenho palavras, mas Tia Leah pode ser considerada uma das pioneiras do Vôlei de Praia na cidade do Rio de Janeiro" (N№̂, 2009).

O Vôlei de Praia teve outro pioneiro, "Coqueiro", como ficou conhecido o professor de Educação Física Luiz Eduardo Pons. Nascido em 1927, dedicou sua vida ao Voleibol. Jogador desde 1945, simultaneamente no Clube Tabajaras e na praia de Copacabana, divulgou o Vôlei de Praia e foi um dos responsáveis em 1950, pela realização dos primeiros torneios com patrocínio no Rio de Janeiro.

Naquela época só se jogava de seis, não havia quadras ou duplas na praia. Com o tempo, às vezes faltava alguém para completar o sexteto, então começaram a jogar com duas, três ou quatro pessoas. Foi quando as pessoas descobriram que era mais emocionante jogar de duplas. Este início foi realizado no Posto Seis, 
nas redes da $D$. Bebê, do Frazão, seu Tomás, e depois da Tia Leah. Nestas redes jogavam toda a elite do Vôlei de Praia, como também dos clubes que disputavam o campeonato carioca. Todo voleibolista que vinha ao Rio jogava com eles - os melhores jogadores dos EUA sempre jogaram nessas redes. Após algum tempo, Coqueiro resolveu montar sua própria rede na praia de Ipanema, em frente à Rua Montenegro (hoje Vinícius de Moraes). Este local era frequentado pela elite do Rio. Foi nesta época que ele começou a participar e organizar torneios de Vôlei de Praia. O Jornal dos Sports patrocinou campeonatos durante 10 anos (...). Depois o Correio da Manhã veio com mais torneios. (COQUEIRO, disponível em http://www.coqueiroeventos.com.br/coqueir o/coqueiro.html.

A prática do Vôlei de Praia em Copacabana parecia se alastrar pela orla. Em 1952, aos 13 anos, Moraes (2009), também pioneira no Vôlei de Praia, disse que começou a jogar na praia, e jogava com os meninos da rua em frente à Rua Joaquim Nabuco. Um ano depois, em 1953, estava jogando no Fluminense, convidada pelo professor Paulo Azeredo. Lúcia descreveu ainda a forma como se jogava naquela época e recordou com orgulho ter participado de torneios $4 \times 4$ com os jogadores Bernard, Bernardinho, Renan. Amaury, William, Montanaro e Xandó no auge dos anos 1980. Sobre seu início, lembrou:

Meus primeiros passos no Voleibol foram no colégio Mallet de Soares, com a professora Iná Ferraz. Também gostava de jogar na praia, perto de casa; ora na rede entre as Ruas Julio de Castilhos e Francisco Sá, no prédio Igrejinha, ora na rede da Tia Leah. Não existia rivalidade entre as redes, o que mais importava era o convívio social entre nós e os filhos que cresceram ali. Havia respeito e amizade, mesmo quando estávamos na Seleção e nos clubes. (MORAES, 2009)

O Vôlei de Praia teve vários astros em sua fase inicial no Rio de Janeiro. Uma referência deste período foi João Carlos da Costa Quaresma, "jogador completo", segundo Leah (2009). Atuou entre os anos 1950 e 1966 nas quadras, inclusive na Seleção Brasileira, e na praia. Sobre a participação das mulheres nos torneios de praia, Quaresma declarou que:

Não havia torneios só para mulheres; e estes eram patrocinados por jornais: Correio da Manhã e Jornal dos Sports em Copacabana, e uma vez pela Coca-Cola na praia do Leblon. Grandes jogadoras do passado: Marly, Enedina, Leila Peixoto, Lúcia Mendes, Marina, Hilda, Maria Alice, Marcinha e Eunice Rondino. (QUARESMA, 2009)

As palavras de Quaresma se confirmam com as boas lembranças de Affonso Mac-Dowell, que participou do Torneio de Vôlei de Praia do Jornal dos Sports de 1963. Jogador de Voleibol nas quadras de 1956 a 1964 e treinador no Rio de Janeiro dos anos 1960 aos 1980, comenta sobre a composição das equipes:

O formato das equipes era: $6 \times 6$ masculino, e misto de três mulheres e três homens. A mulher de maior destaque nos anos 1960-1970 foi Marly Álvares. As principais redes eram as do Posto Seis e a rede Olinda no Posto Três e Meio, em Copacabana, e Montenegro e Castelinho em Ipanema. (MAC DOWELL, 2009)

Ballariny liga o início do Vôlei de Praia nos anos 1940 à disputa dos jogos entre duplas e 4x4. Mas nos anos 1950 já se jogava 6×6, inclusive misto, formado por três homens e três mulheres.

Entre as mulheres lembro-me da Hilda e da Gilda nos anos 1940-1950, e nos anos 1960, a Lúcia, a Marly (que depois foi técnica da AABB) e a Eunice, que tinha uma rede em frente ao Hotel Olinda, em Copacabana. Foi neste período que as mulheres começaram a aderir mais ao esporte. Nos anos 1970, o destaque foi Ana Lílian, que também jogava em clube, Fluminense, e na praia de Ipanema participou de vários torneios. Antes dos anos 1980 já começavam a surgir a Jaqueline, que jogava no Flamengo; a Rosita, que jogou no Botafogo, a Rose, mulher do Vitinho. Nos anos 1990, também gostava muito de ver a Mônica do Jorjão; jogando, ela levantava e atacava muito bem. (BALLARINY, 2009)

Algumas mulheres que jogavam em clubes também apreciavam a modalidade que brotava nas areias da orla carioca. Grande jogadora de Voleibol, integrante da Seleção Brasileira nas décadas de 1960-1970, Helenize de Freitas, chamada por todos de Belê prima de Bebeto de Freitas $^{3}$, atuou como levantadora e cortadora. Jogadora completa, também participou desta época, e contou sobre o Vôlei de Praia:

Havia uma rede no Posto Seis em Copacabana, em que meu primo, Bebeto, jogava sempre. Com ele jogavam: Vitinho, Feitosa, Barata, Paulão. Tenho esta lembrança de quando vinha ao Rio de Janeiro passar férias na casa do Bebeto. Sobre Bebeto, lembro-me que seu pai implicava com ele, porque ele vivia na praia jogando Vôlei. (FREITAS, 2008)

A oportunidade de sair das quadras para jogar Vôlei de Praia nas areias era uma novidade, e Marly Álvares, jogadora carioca da Seleção Brasileira entre os anos 1948 e 1972, e técnica na década de 1970, também aproveitou este momento. Segundo ela, "o maior movimento do

\footnotetext{
${ }^{3}$ Jogador da Seleção Brasileira de Voleibol nas Olimpíadas de 1972 (Monique) e 1976 (Montreal), o carioca Paulo Roberto de Freitas foi atleta, técnico e manager do time de vôlei Santa Bárbara Spikers, na Califórnia, na década de 1970. Assumiu a Seleção Brasileira Masculina de Voleibol e foi medalha de prata no Campeonato Mundial de 1982 e na Olimpíada de Los Angeles, em 1984. Comandou a Itália na conquista do campeonato mundial de 1998.
} 
Vôlei de Praia feminino foi nos anos 1962-1963, e as mulheres estavam lá, inclusive eu. Jogava quartetos e sextetos e o sistema de disputa utilizado nos torneios, era o de eliminatória dupla" (ÁLVARES, 2009).

\section{As regras da rede da Tia Leah}

No "pacote" de regras da Tia Leah destacavam-se: (a) era vetado atacar forte em cima dela (regra válida somente para os mais jovens), (b) somente se permitia a entrada na quadra daqueles que passavam pelo seu aval, faziam parte de sua equipe e respeitavam as normas preestabelecidas. Para não participar do esquema de regras impostas ao jogo, alguns frequentadores driblavam Tia Leah, chegando para jogar após o horário em que "a generala" estava presente em quadra, assim como outros jogadores, parceiros de idade avançada. Estes aproveitavam o momento em que ela se banhava no mar para falar palavrões e até brigar. Em sua presença, jamais eram permitidas discussões. (PEIXOTO, 1995).

Nas práticas esportivas na praia, as decisões ali desenvolvidas quanto às regras de convívio eram corresponsabilizadas, fazendo parte aqueles que escolhem aceitá-las ou driblá-las. Em práticas esportivas de lazer, fica por conta dos jogadores o estabelecimento das regras que compõem o contrato lúdico. Nestes anos de dedicação de Tia Leah à sua rede, os jogadores não só aceitavam as condições traçadas por ela como reconheciam nela a posição de "chefia da quadra".

O jogo disciplinado, sem brigas e contratempos era desejo de todo grupo de elite do Vôlei de Praia adepto da rede de Tia Leah. Os critérios adotados justificavam o desejo de ordem e disciplina na rede. Era comum receber sem agendamento prévio a visita de fotógrafos no local. Com a presença de jogadores do Voleibol de clubes, nos anos 1970-1980, tornou-se rotina canais televisivos e jornalistas clicarem imagens e fazerem entrevistas na rede.

Depois de tanta dedicação, jogando e disciplinando a sua rede, Tia Leah passou a ser somente gestora da rede, controlando as regras e parcerias a serem feitas, assim como assistindo seus "pupilos" jogando.

Quanto às regras do jogo de Vôlei de Praia, Leah (2009) afirmou: "Eram as mesmas regras do Voleibol de quadra. O saque [...] dependendo de quem ia sacar, alguns gostavam de sacar por cima. Eu só sacava por baixo [risos (...)]". Ballariny lembra alguns detalhes da forma de jogar:
Naquela época não tinha manchete, era o "bandejão". Uma forma de ataque era a puxada ou agarrada. O saque era o americano (de lado, rodando) ou o saque tênis ou o saque por baixo. Os uniformes eram calções brancos com o número no calção preso por um alfinete [referese aos torneios do Jornal dos Sports a partir de 1948]. (BALLARINY, 2009)

\section{Os freqüentadores da rede da Tia Leah}

Peixoto (1995) relata que o jogador antigo (homem de mais idade), freqüentador da rede da Tia Leah, tinha dois objetivos: o de uma simples paquera e o da prática do esporte. Há uma tradição de que a praia, lugar descontraído, atraente pela naturalidade das pessoas e do espaço, é um local de encontros casuais e de possíveis conquistas. Tia Leah, ao organizar as equipes, dava preferência à escalação de suas companheiras de idade, pois reconhecia a disputa dos homens por mulheres mais jovens na sua rede. Ela protegia as mulheres e, verdadeira estrategista, escolhia para o seu time os mais jovens, que representavam mais vigor no deslocamento na areia, o que garantia um jogo bonito e limpo.

Muitos nomes passaram em sua rede nos anos 1930-1940. Leah (2009), em seu depoimento, destacou "Everest como o melhor jogador entre os homens e Hilda Lassen entre as mulheres; depois surgiu Lucia, minha sobrinha". Nos anos 1970-1980, uma nova geração começou a frequentar a rede, e aquele que Tia Leah mais gostava de ver jogar era o Renan (atacante da Seleção Brasileira Masculina de Voleibol).

O Everest jogou muito na minha rede, tinha boa visão de jogo, era um grande jogador, tinha uma cabeça muito boa. Lembro do Lúcio, Coqueiro, Átila, que também foram grandes jogadores. Entre as mulheres, Hilda Lassen, da Seleção Brasileira, mulher do Celinho, que também jogou na minha rede. Lucia, minha sobrinha, freqüentava a rede, foi da Seleção Brasileira, jogava quadra e praia. Mas o melhor de todos foi o Renan, ele era muito bom. (LEAH, 2009)

\section{A rede e as lentes da mídia}

A rede de Tia Leah transformou-se em uma vitrine. Por lá passaram os astros do Voleibol da época e os atletas da "geração de prata" 4. O carinho e a cordialidade foram a tônica desta rede. Leah fazia as honras da casa; tinha a inscrição da rede legalizada no Corpo de

\footnotetext{
4 A renomada Seleção Brasileira Masculina de Voleibol composta por: Willian, Fernandão, Bernard, Renan, Xandó, Amauri, Montanaro, Badalhoca, Ruy, Ronaldo, Maracanã, Bernardinho e Marcos Vinícius, além da medalha de prata no campeonato mundial em 1982, também conquistou o segundo lugar nos Jogos Olímpicos de Los Angeles, em 1984. Daí a denominação de "geração de prata".
} 
Bombeiros $^{5}$, pagava uma taxa anual, o que the valia um ar de proprietária da rede, com todo respeito.

Leah, sempre vaidosa, gostava de passar batom nos lábios, tinha a pele bronzeada, cabelos grisalhos penteados, usava maiô e chapéu de praia. Lucia comenta que alguns diziam que ela estava sempre combinando a cor do maiô com a cor dos olhos: azuis. Um estilo que registrava a sua marca e o seu charme, mesmo depois dos 70 anos, deixando-a sempre pronta para fotos ou filmagens que eventualmente aconteciam em sua rede.

Os atletas da "geração de prata" que jogavam na rede da Tia Leah eram chamados de "colunáveis", e atraíam a mídia, que sempre passava para fazer uma matéria na rede. "Ela gostava, trazia prestígio e glamour para a rede de Vôlei de Praia, e era a TV Globo, emissora de maior visibilidade à época" (MORAES, 2009).

O grande reconhecimento da rede da Tia Leah, se deu na década de 1980, com o surgimento da parceria clube-empresa. As pioneiras: Atlântica Boa Vista (RJ) e Pirelli (SP) trouxeram maior visibilidade aos jogadores da Seleção Brasileira de Voleibol de quadra, e Bebeto de Freitas, que estava no comando da Seleção Brasileira Masculina, reaproximou-os de Tia Leah.

Responsável por este reconhecimento, Bebeto de Freitas, filho adotivo da rede da Tia Leah (palavras de Leah) desde criança, passou a levar seus jogadores da Seleção Brasileira para jogar na areia após os treinamentos na Escola de Educação Física do Exército (EsEFEx), na Urca (RJ) em busca de uma melhora física. Com a invasão de jogadores renomados aos palcos das areias, o Vôlei de Praia ganhou popularidade principalmente em Copacabana e Ipanema, no Rio de Janeiro. Jogadores da então "geração de prata" começaram a ser convidados a participar de eventos esportivos na praia, como exibição, a exemplo do I Torneio Hollywood em 1985, organizado pela Koch Tavares ${ }^{6}$, e assim deu-se início à grande massificação e ascensão do Vôlei de Praia.

\section{Os jogos, espetáculo para o público}

O público gostava de assistir aos jogos, e os banhistas também. A calçada ficava cheia (LEAH, 2009; BALLARINNY, 2009, NONÔ, 2009). "Seu" Nonô lembra que o público estava sempre no

\footnotetext{
${ }^{5}$ Órgão que fiscaliza a permanência e localização das redes na orla a cidade do Rio de Janeiro.

6 - Disponível em: http://www.kochtavares.com.br/volei.htm Acesso em: 14 maio 2009.
}

calçadão, apoiando os jogadores e vibrando com as jogadas, Copacabana fomentou o desenvolvimento do Vôlei de Praia no Rio de Janeiro.

Um dos momentos de maior expectativa do público era quando Bernard comparecia à rede e executava o saque "Jornada nas Estrelas" 7 . No auge dos anos 1980, sua presença atraía os transeuntes para admirar e aplaudir jogadas sensacionais. Muitas vezes era possível assistir a um espetáculo sem o compromisso de uma atuação profissional do jogador. Segundo Peixoto (2000, p.118), o público mais fiel aos jogos da rede da Tia Leah era formado por aqueles que não mais jogavam como titulares e que gostavam de uma boa conversa com os amigos e de participar da roda social formada em volta da "rainha da rede", fosse à rede ou nos bancos do calçadão de Copacabana. Alguns jogadores eram somente "figurantes no banco de reservas", aposentados, mas assíduos nos compromissos da rede. Desempenhavam um papel de "críticos esportivos e políticos de plantão". Na verdade, uma forma de pertencimento simbólico àquele local que trazia certo status.

Maffesoli (2005) sugere que "a vida é feita de jogo, de encenação, de astúcia, de ousadia e, principalmente, dos 'insignificantes' acontecimentos de cada dia". (p. 55) Nesse sentido, parece que estar em torno da rede de volei de Tia Leah significava fazer parte de um acontecimento.

As praias do Rio de Janeiro identificam-se por estimular um convívio interpessoal em um espaço coletivo. O esporte nas quadras de Vôlei de Praia reunem freqüentadores da mesma "área", ou amantes do esporte, constituindo-se em verdadeiras tribos.

\section{Carreiras que se cruzaram nas malhas da rede de Tia Leah}

Tia Leah, A maior incentivadora do Vôlei de Praia no Rio de Janeiro, administrou durante mais de trinta anos a rede do Posto Seis. Ali, vários jogadores deram seus primeiros passos, entre eles Bernardinho e seu irmão Dudu, Bebeto de Freitas, Jaqueline - medalha de ouro olímpico em 1996 -, que iniciou no Voleibol em 1972, nas areias da rede da Tia Leah, onde seu pai jogava com os amigos. Valporto (2006 p. 111) relata que a praia de Copacabana era o playground da família de Jaqueline. E ainda Rose e Roseli, que

\footnotetext{
${ }^{7}$ Saque executado por Bernard, do Voleibol nos anos 1980 que atingia uma altura com trajetória altíssima, quase alcançando o teto dos ginásios. O jogador começou a praticálo na praia.
} 
depois formaram uma dupla bem colocada em todas as competições que disputavam.

Nas décadas de 1970-1980, além dos freqüentadores comuns, a rede de Tia Leah recebia grande concentração de jogadores e exjogadores de Voleibol, do Brasil e do exterior, muitos deles renomados, como os nossos craques da "geração de prata".

Os anos 1990 foram marcados por mulheres que passaram por esta rede, entre as quais três medalhistas de prata em olimpíadas: Mônica Rodrigues, Adriana Samuel e Adriana Behar. Posteriormente outras jogadoras registraram seus nomes na história do Vôlei de Praia com o início do Circuito Banco do Brasil em 1992.

Valporto (2006) relata que em 1991 Mônica Rodrigues jogava na quadra com a equipe Rio Forte, treinada por Marco Aurélio, que dizia não se importar que ela jogasse também na areia, desde que não atrapalhasse seu desempenho na quadra. Foi em um torneio organizado pela prefeitura do Rio de Janeiro que Mônica jogou pela primeira vez (oficialmente) com uma amiga de Ipanema, Débora, vencendo Rose e Roseli, as favoritas na época. Em 1992 Mônica abandonou as quadras e passou a se dedicar à praia; cinco anos depois, nos Jogos Olímpicos de Atlanta, conquistava a medalha de prata junto com Adriana Samuel, irmã de Tande ${ }^{8}$. Mônica treinava em um ginásio na Urca e pelas manhãs, após o treinamento, ia diretamente para Copacabana jogar Vôlei de Praia na rede da Tia Leah. Lá, Mônica participava de jogos de duplas junto com Bernard, Badalhoca e outros jovens que sonhavam com o novo esporte que surgia. Desde 1986, a Confederação Brasileira de Voleibol já organizava competições internacionais nas praias do Rio de Janeiro.

Com o fim da equipe carioca Rio Forte, em 1992, Mônica convidou sua amiga Adriana Samuel, que desejava permanecer jogando na cidade do Rio de Janeiro, para jogarem juntas na praia, formando uma dupla. O convite foi aceito e o local para ingressar na nova modalidade nada mais era do que a rede da Tia Leah. Segundo Valporto (2006, p. 140), Adriana dizia: "Essa Mônica é uma 'rata de praia', eu nunca vou me acostumar com isso". Pouco depois já estavam jogando a Copa Itaú ${ }^{9}$ e conquistando o vicecampeonato. Os treinamentos se intensificaram e em 1993 já se preparavam para a competição nacional.

\footnotetext{
${ }^{8}$ Campeão olímpico com a Seleção Brasileira de Voleibol em Barcelona, 1992, em uma conquista histórica contra a Holanda por 3x0, dirigida pelo técnico José Roberto Guimarães.
}

Adriana Behar, jogadora de Voleibol regressava ao Rio de Janeiro em 1991 após uma temporada na Itália. A casa de seus pais ficava em Copacabana, no Posto Seis, próxima à rede da Tia Leah, e Adriana logo percebeu a explosão do Vôlei de Praia na cidade e o quanto este esporte mostrava-se um potencial entre os cariocas. Parecia ser uma nova opção de vida, de carreira, um novo desafio. Em seu período de férias do Voleibol italiano, Adriana aproveitou para experimentar a nova modalidade, jogar na praia e conhecer um pouco mais do esporte. Logo que retornou ao campeonato profissional na Itália, soube que a Confederação Brasileira de Voleibol, implantava no país o Circuito Banco do Brasil, que se tornaria a maior competição brasileira. Adriana Behar se entusiasmou com as notícias, rescindiu o contrato com o clube italiano e voltou ao Brasil para se dedicar ao Vôlei de Praia. Sua primeira parceira nas areias foi Ana Richa, levantadora da Seleção Brasileira nos anos 1980-1990, que encontrou jogando na rede da Tia Leah. Nos Jogos Olímpicos de Sidney/2000 e Atenas/2004, Adriana Behar foi medalha de prata ao lado de Shelda, com quem formou dupla durante dez anos (VALPORTO, 2006, p.163).

\section{Considerações Finais}

Sendo dada a palavra àqueles e àquelas que vivenciaram os papéis de jogadores e de observadores dos jogos de Vôlei de Praia, emergiu desses discursos uma rede de imagens que expôs um esporte que nasceu da sociabilidade de jogadores homens e mulheres em quadra e que cresceu rumo à competitividade. Nessa rede surgiu também a imagem de uma mulher gestora que protagonizou a história do Vôlei de Praia na cidade do Rio de Janeiro, em especial no Posto Seis, na praia de Copacabana. Por tais procedimentos, pode-se acompanhar a ascensão deste esporte e o aparecimento de mulheres que registraram seus nomes no esporte nacional e mundial.

Percebeu-se uma concomitância nas informações colhidas no dia-a-dia do Vôlei de Praia com a literatura encontrada sobre a personagem em questão: Tia Leah, que conseguiu contextualizar uma história real em seu tempo e cultura. A partir de uma reorganização do passado, baseado em lembranças vividas no Vôlei de Praia, encontrou-se a possibilidade de mostrar uma identidade sociocultural do Vôlei de Praia entre os anos 1930 e 1990.

\footnotetext{
${ }^{9}$ Torneios organizados com o patrocínio do Banco Itaú, anos 1990.
} 
O interesse em investigar a importância de Tia Leah no Vôlei de Praia, construída a partir de memórias, confirmou a presença da sociabilidade como fator fundamental deste período, contribuindo para o convívio de diversas gerações.

O principal objetivo das pessoas naquele espaço a céu aberto, especificamente nas delimitações da rede da Tia Leah, era fazer parte de um grupo social onde participavam com a motivação orientada por objetivos comuns: o jogo em si. Ainda que fosse fato a obediência às regras ditadas por uma pioneira do Vôlei de Praia, esta se apresenta entre os entrevistados como uma personagem querida, carismática, elegante em seu estilo e controladora com suas imposições nos jogos. Ela oferecia aos participantes da sua rede um intercâmbio de relações sociais entre pessoas de idades variadas, contrastando com os grupos que se espalhavam ao longo da orla, fechados de acordo com os respectivos interesses, limitando-se às vezes à mesma idade. Desta forma foi possível constatar a inter-relação entre jogadores, exjogadores e frequentadores auxiliando na autoestima de vários destes participantes, que por vezes poderiam estar se sentindo desvalorizados, desconhecidos ou sem oportunidades de desfrutar seus momentos de lazer.

Ficou evidente a preferência da anfitriã, Tia Leah, por ser favorecida ao final de cada jogo como a equipe vencedora, quando ficava declarada a escolha por jogadores mais fortes, jovens e competentes para serem seus parceiros.

Leah foi pioneira na gestão não-formal de um esporte que cedo se organizou institucionalmente e não perdeu o caráter de prática como lazer, ampliando a adesão de inúmeros jogadores. Suas características de mulher que comandava e que organizava distribuindo funções fogem do perfil das mulheres da época, submissas às ordens de um homem.

Seu carisma, magia e orgulho lhe deram a condição com que se apresenta perante o esporte. Uma mulher capaz de estar à frente do Vôlei de Praia com honrarias por sua contribuição ao esporte, acolhendo a todas as gerações de jogadores de Voleibol e participando efetivamente da iniciação e paixão de uma geração de mulheres vitoriosas. Mesmo sem ter jogado em clubes e Seleções, destacou-se fora das quadras gerenciando sua rede, que serviu de arena principal no dia-a-dia do carioca e favoreceu a adesão do público que, no imaginário de jogadores, se tornou mais um jogador em campo, apoiando como torcedores. Em 1989, Tia Leah já era conhecida como um ícone do Vôlei de Praia. Sua presença na gestão da rede do Posto Seis foi um dos marcos no esporte, dando suporte à divulgação e visibilidade do esporte e à igualdade nos papéis entre homens e mulheres que por ali passaram.

\section{Referências}

ALBERTI, V. Manual de história oral. 2. ed. Rio de Janeiro: Editora FGV, 2004.

ÁLVARES (Marly Álvares): depoimento escrito [set. 2009]. Entrevistador: Affonso Mac- Dowell. Rio de Janeiro, 2009.

BALLARINY (José Garcez Ballariny): depoimento [mar. 2009]. Entrevistadora: Lenice Peluso. Rio de Janeiro: Copacabana, 2009. (55 min.), formato amr, 5,1MB.

COQUEIRO, L. E. Pons. Coqueiro. Disponível em:

http://www.coqueiroeventos.com.br/coqueiro/coqu eiro.html. Acesso em 22 fev. 2009.

CORBIN, A. Território do vazio? A praia e o imaginário ocidental. São Paulo: Companhia das Letras, 1989.

COSTA, V. L. M.; TUBINO, M. J. G. Esportes praticados na areia da praia: representações simbólicas do espaço lúdico. Arthus, Revista de Educação Física e Desportos, Rio de Janeiro. Ed. Universidade Gama Filho, v. 18, p. 27-37, 1998.

FREITAS (Helenize de Freitas "Belê"). Publicação eletrônica [mensagem pessoal]. Mensagem recebida por<lepeluso@gmail.com> em 26, 28, 29 maio 2008.

GOELLNER , S. V.. Bela, maternal e feminina: imagens da mulher na Revista Educação Physica. ljuí: Unijuí, 2003. 152 p. (Coleção educação física).

HALBWACHS, M. A memória coletiva. São Paulo: Vértice, 1990.

JORNAL DOS SPORTS. Quatro partidas amanhã e cinco no domingo, o próximo cartaz: duas atraentes rodadas com jogos de astros e estrelas. Rio de Janeiro, 3 jan. 1947, p. 1.

LEAH (Leah Mendes de Moraes): depoimento [mar. 2009]. Entrevistadora: Lenice Peluso. Rio de Janeiro: Copacabana, 2009. (15 min.), formato amr, 1,4MB.

MAC DOWELL (Affonso Mac-Dowell): depoimento escrito [set. 2009]. Entrevistadora: Lenice Peluso. Rio de Janeiro, 2009. 
MAFFESOLI, M.. O mistério da conjunção ensaios sobre comunicação, corpo e sociabilidade. Porto Alegre: Sulina. 2005.

MORAES (Lucia Mendes de Moraes): depoimento [abr. 2009]. Entrevistadora: Lenice. Peluso. Rio de Janeiro: Copacabana, 2009. (59 min.), formato amr, 5,5 MB.

MOURÃO, L. A representação da mulher brasileira na atividade física desportiva: da segregação à democratização. 1998. Tese (Doutorado em Educação Física) - Programa de Pós-Graduação em Educação Física, Universidade Gama Filho, Rio de Janeiro, 1998.

NORA, P. Entre memória e história: a problemática dos Iugares. São Paulo: Educ., 1993.

OS REIS da praia. Tia Leah a rainha da praia. Vôlei de Praia, Rio de Janeiro. ano 1, n. 1, p. 30, 1990.

PEIXOTO, C. E. A sociabilidade dos idosos cariocas e parisienses: em busca de estratégias para preencher o vazio da inatividade. Revista Brasileira de Ciências Sociais, São Paulo, ano 10, v. 27, p. 138-149, 1995. 1995. Disponível em: http://www.anpocs.org.br/portal/publicacoes/rbcs_ 00_27/rbcs27_09.htm>. Acesso em: 18 mar. $200 \overline{0}$.

\section{Envelhecimento e imagem. As}

fronteiras entre Rio de Janeiro e Paris. São Paulo: Annablume, 2000. p. 116-120.

\section{PEIXOTO, F. M. A verdadeira história do}

futevôlei. Carta enviada ao jornal Globo - Bairro: Copacabana e Ipanema, em 21 de fevereiro de 1987.

PEÑA, N. M.; ECHEVERRY, L. G. J.

Investigation qualitativa: la complementariedad etnográfica. Armênia. Colômbia: Editorial Knesis, 2000.

QUARESMA (João Carlos da Costa Quaresma): depoimento escrito [set. 2009]. Entrevistador: Affonso Mac- Dowell. Rio de Janeiro, 2009.

NONÔ (Claudionor José da Silva): depoimento [mar. 2009]. Entrevistadora: Lenice Peluso. Rio de Janeiro: Copacabana, 2009. (35 min.), formato amr, 3,2MB.

TIA LEAH: "a musa do vôlei". Posto Seis, Rio de Janeiro, ano 2, n. 19, p.13, 1997.

TUBINO, M. J. G. Dimensões sociais do esporte. 2. ed. revista. São Paulo, Cortez, 2001.
O que é esporte. 3. ed. São Paulo:

Brasiliense, 2006.

VALPORTO, O. Atleta, substantivo feminino. Rio de Janeiro. Casa da Palavra, 2006.

\author{
Endereço: \\ Lenice Peluso de Oliveira \\ Av. Jornalista Ricardo Marinho 450/104 \\ Barra da Tijuca \\ Rio de Janeiro RJ Brasil \\ 22631-350 \\ Telefone: (21) 24310959 \\ e-mail: lepeluso@hotmail.com
}

Recebido em: 25 de outubro de 2009.

Aceito em: 28 de janeiro de 2010.

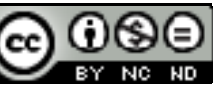

Motriz. Revista de Educação Física. UNESP, Rio Claro, SP, Brasil - elSSN: 1980-6574 - está licenciada sob Licenca Creative Commons 